\title{
Rhizosediments of Salicornia tegetaria Indicate Metal Contamination in the Intertidal Estuary Zone
}

\author{
Marelé A. Nel1,2,3*, Gletwyn Rubidge ${ }^{4}$, Janine B. Adams ${ }^{1,2}$ and Lucienne R. D. Human ${ }^{2,3 *}$ \\ ${ }^{1}$ DSI/NRF Research Chair, Shallow Water Ecosystems, Nelson Mandela University, Port Elizabeth, South Africa, \\ ${ }^{2}$ Department of Botany, Nelson Mandela University, Port Elizabeth, South Africa, ${ }^{3}$ South African Environmental Observation \\ Network (SAEON) Elwandle Coastal Node Nelson Mandela University, Port Elizabeth, South Africa, ${ }^{4}$ Department \\ of Chemistry, Nelson Mandela University, Port Elizabeth, South Africa
}

\section{OPEN ACCESS}

Edited by:

Dragana S. Đorđević,

University of Belgrade, Serbia

Reviewed by:

Pedro Aboim De Brito,

Instituto Português do Mar e da

Atmosfera (IPMA), Portugal

Enrique Mateos-Naranjo,

Seville University, Spain

*Correspondence:

Marelé A. Nel

marele.anne@outlook.com

Lucienne R. D. Human

Lucienne.Human@saeon.ac.za

Specialty section:

This article was submitted to

Toxicology, Pollution and the

Environment,

a section of the journal

Frontiers in Environmental Science

Received: 15 June 2020 Accepted: 02 September 2020

Published: 30 September 2020

Citation:

Nel MA, Rubidge G, Adams JB and Human LRD (2020)

Rhizosediments of Salicornia tegetaria Indicate Metal Contamination

in the Intertidal Estuary Zone.

Front. Environ. Sci. 8:572730.

doi: 10.3389/fenvs.2020.572730
Metal pollution is a well-known anthropogenic impact of highly developed estuaries, with dire consequences to the ecosystem. This study investigated the metal concentrations (Al, Cr, Cu, Fe, Mn, Ni, Pb, Zn) in the sediment colonized by Salicornia tegetaria, a dominant salt marsh plant in the lower intertidal zone of the Swartkops Estuary. The samples were collected at five sites along the banks of the middle and lower reaches of the estuary, and analyzed using an Inductively Coupled Plasma -Optical Emission Spectrometer. Metal contamination was determined using established normalized baseline models. It was found that all the sites contained metal enrichment, with the estuary mouth experiencing the least enrichment. Salicornia tegetaria holds a substantial amount of anomalous metals within its rhizosediment-providing a valuable ecosystem service to a highly developed Swartkops Estuary.

Keywords: metal pollution, Swartkops Estuary, baseline, coupled plasma optical emission spectrometer, salt marsh

\section{INTRODUCTION}

Estuaries are historically convenient places to build industries, as it was deemed a suitable place to dispose of large quantities of urban and industrial waste into the ocean (Forstner and Wittman, 1981). At the time it was judged to be appropriate, as rivers can transport and deposit waste into the ocean, which was considered to be so vast that it is insurmountable. Thus, metal pollution into estuaries is a well-known occurrence. Metals form part of various industrial processes, producing general products for consumers (Crane et al., 2017; Peppicelli et al., 2018). Once the waste and products are discarded, it adds to the naturally occurring metals in the sediment. Metals are commonly adsorbed onto the surface of sediment components, or dissolved in porewater (Basta et al., 2005; Almeida et al., 2008). These characteristics allows the sediment to act as a sink for metals, and mediates the release to the biological environment (Tack and Verloo, 1995; Strawn et al., 2015). The capacity for the sediments to retain the metals are limited to its physical and chemical characteristics, i.e., granulometric fraction, $\mathrm{pH}$, oxidation-reduction potential and organic matter content are all important factors to include when assessing the bioavailability of metals 
in sediments (Impellitteri et al., 2001; Navas et al., 2005; Carrillo -Gonzalez et al., 2006; Kabata-Pendias, 2011). However, metal behavior in sediments is far from simple, and these characteristics are not always applicable at the same extent, for other regions with different physico-chemical and biological interactions.

Wetlands play a crucial role in the biogeochemistry of trace elements in estuaries and provide a major sink for these elements (Caçador et al., 2009; Vodyanitskii and Shoba, 2015; Bonanno et al., 2018). The Swartkops Estuary is a very important socioeconomic and environmental asset and has high biodiversity importance for in terms of fish, birds and plants (Turpie et al., 2002; Adams, 2020). It has a large intertidal salt marsh area and Salicornia tegetaria is a dominant species, but it only earns a botanical importance rating of $41-45$ out of 100 , due to the modifications to the system brought on by the development (Colloty et al., 2000). The accumulation of metals into the bottom sediments make these habitats particularly vulnerable to the impacts of metal toxicity. This is of concern due to the prevalent trend of environmental problems caused by metal pollution, which turns pristine environments toxic (Forstner and Wittman, 1981; Bonanno et al., 2017). However, some plant species can tolerate seemingly toxic metal levels and concentrate them into their below- or above-ground organs (Williams et al., 1994; Olguín and Sánchez-Galván, 2012). Moreover, some plant species can manipulate the bioavailability of metals in the sediments (Reboreda and Caçador, 2007; Duarte et al., 2010). Several wetland plants can also act as bioindicators of metals (Phillips et al., 2015), and can be used in ecological engineering in environmental management strategies. Estuary habitats are some of the most productive in the world and provide several crucial ecosystem services, namely: (1) nursery areas for marine fish, (2) a path for migratory marine and bird species, (3) habitat for important and endangered wetland ecosystems (saltmarsh, mangroves, seagrass beds), (4) transportation for nutrients and organic materials to coastal habitats, (5) carbon sequestration, and (6) the containment of endemic species dependent on the estuarine ecosystem (Roy et al., 2001; Turpie et al., 2002; Barbier et al., 2011; NBA, 2012; Adams, 2020).

A simple question of potential metal contamination in an area can become complicated without historical baseline data for comparison. Separating the naturally occurring metal concentrations from the contaminants is a challenge. Sediment Quality Guidelines (SQGs) are often used to compare current metal concentrations where historical data are unavailable. However, the SQGs are based on concentrations that are adverse to the ecosystem or human activity (Long et al., 1995), and cannot give an indication of in situ metal contamination. Sediment with comparably higher concentrations of metals compared to other areas can also not be assumed to be metal-contaminated. The research by Newman and Watling (2007) used these insights as a means to create geochemical baseline models for geological areas of the south-eastern coast of South Africa, between the Kromme Estuary in Cape St. Francis and the Nahoon Estuary in East London. Geochemical normalization compares the metal concentration with a reference element that follows crustal decomposition (Karageorgis et al., 2009).
The ratio of metal: normalizer is only comparable due to the stability of the normalizer within the area. Aluminum is often used as a normalizer in estuarine and coastal sediment (Kersten and Smedes, 2002). A stable metal will have little increase or decrease in their concentration. Aluminum concentrations are naturally high in sediment, being the third most abundant element in the earth's crust (Turekian and Wedepohl, 1961; Kring, 1997). The normalizer element can only be used when it's anthropogenic input is negligible (Almeida et al., 2008). Aluminum fits these criteria as anthropogenic inputs are not likely to be significant enough to affect its levels (Schropp et al., 1990). Iron (fourth most abundant element in the earth's crust) is often not suitable, due to its close association with manganese, which concentrates iron in the metal surface (Douglas and Adeney, 2000).

The Swartkops Estuary is located within the Nelson Mandela Metropolitan, South Africa. The estuary flows through highly urbanized and industrialized developments that began in the first quarter of the 19th century (Theal, 2010). Historical data does not include metal baseline concentrations specific to the area, so it is difficult to assess the impacts of industry and urbanization on the biota. Indeed, "there is a lack of baseline data of pollutants in the sediments and biota in the estuaries of South Africa" (NBA, 2012). Instead, studies have compared the metal concentrations to other datasets available from the 1970s-more than 150 years after the initial developments. Studies agree that the rate of metal accumulation has increased throughout the Swartkops Estuary, in some cases more than $100 \%$ for $\mathrm{Cr}, \mathrm{Mn}, \mathrm{Pb}$ and $\mathrm{Zn}$ (Binning and Baird, 2001). In 2014 high concentrations were found in the juveniles of popular angling fish, selected invertebrates and in the eggs of gull, exceeding the international food quality guidelines, where applicable (Nel et al., 2015). Other than fishing, the estuary has important recreational and ecological importance, providing numerous essential ecosystem services originating from the diverse salt marsh and seagrass habitats. The estuary has high national botanical importance, because of the large intertidal salt marshes (Colloty et al., 2000; Adams, 2020). The ability of the salt marshes to capture and localize metals and other contaminants is important to maintain a healthy ecosystem. Assessing the extent of metal contamination in the area will provide critical information on how the salt marsh habitats are coping as metal sinks, as well as information for environmental management procedures within the estuary. Salicornia spp. is good at localizing metals in their roots, preventing metals from entering the food chain (Smillie, 2015). Little research has been done on S. tegetaria, a lower intertidal salt marsh species vulnerable to the effect of sealevel rise (Brown and Rajkaran, 2020). In this study, sediment metal concentrations within monoculture stands of $S$. tegetaria, a dominant halophyte within the Swartkops salt marshes, were assessed. The metals analyzed included $\mathrm{Al}, \mathrm{Cr}, \mathrm{Cu}, \mathrm{Fe}, \mathrm{Mn}, \mathrm{Ni}$, $\mathrm{Pb}$ and $\mathrm{Zn}$. The objective of this paper was to investigate the levels of metal contamination within the salt marsh habitat of the Swartkops Estuary. The sediment characteristics were also determined to ascertain the behavior of metals in the salt marsh. In order to determine whether contamination was influenced by anthropogenic sources, a geochemical (normalization) model created by Newman and Watling (2007) was used. This can 
potentially indicate the extent of metal contamination in the marsh, between the approximately 40-year-old datasets used for the models.

\section{MATERIALS AND METHODS}

\section{Study Site and Sampling}

Sediment samples were collected on 30 April 2019 and 01 May 2019 from the saltmarsh of the Swartkops Estuary $\left(33^{\circ} 51^{\prime} 11^{\prime \prime} \mathrm{S}\right.$; $25^{\circ} 36^{\prime} 53^{\prime \prime} \mathrm{E}$ ), which is a predominantly open warm temperate estuary. Five sites were chosen along the middle and lower reaches of the estuary, according to the distribution of plant species. Point source inputs from surrounding catchment activities occur in close proximity to Motherwell Canal (Site 1), Markman Canal (Site 2), Tiger Bay Launch Site (Site 3), Tipper's Creek (Site 4) and Swartkops Estuary mouth (Site 5) (Figure 1). The latter is close to an inactive oyster farm. At each site randomly selected $S$. tegetaria plants were carefully uprooted using a PVC corer (Diameter $=11.2 \mathrm{~cm}$ ). Sediment samples from the rhizosediment were collected at the surface of the cores and stored in polyethylene jars. Five replicates of the sediment samples were collected at each site. The samples were transported in a cooled and insulated container, to the laboratory on the day of collection.

The Motherwell Canal (Site 1) is the furthest site from the mouth and is located just above the actual canal. The canal is connected to 14 stormwater drains and contains a series of litter traps located at regular intervals. The base of the canal is connected to an artificial wetland, which was built to extract the pollutants from the wastewater flowing down the canal. Large volumes of plastic debris and other litter enter the canal from the surrounding developments. The Motherwell township is located along the canal. Approximately $1 \mathrm{~km}$ downstream from Site 1 is the Markman Canal, which transports stormwater effluent from a large industrial area. Site 2 is located downstream from the canal, within a large salt marsh. The Tiger Bay Launch Site (Site 3) is located downstream, on the opposite side of the riverbank. It has an interconnected series of creeks, which contains large stands of eelgrass (Zostera capensis). The Papenkuils River connects to the Swartkops Estuary close to Site 3. This river is very small but flows through a large section of Port Elizabeth (urban and industrial areas) to reach the Swartkops Estuary. The last $8 \mathrm{~km}$ of the Papenkuils river is reinforced with concrete, forming a canal. Site

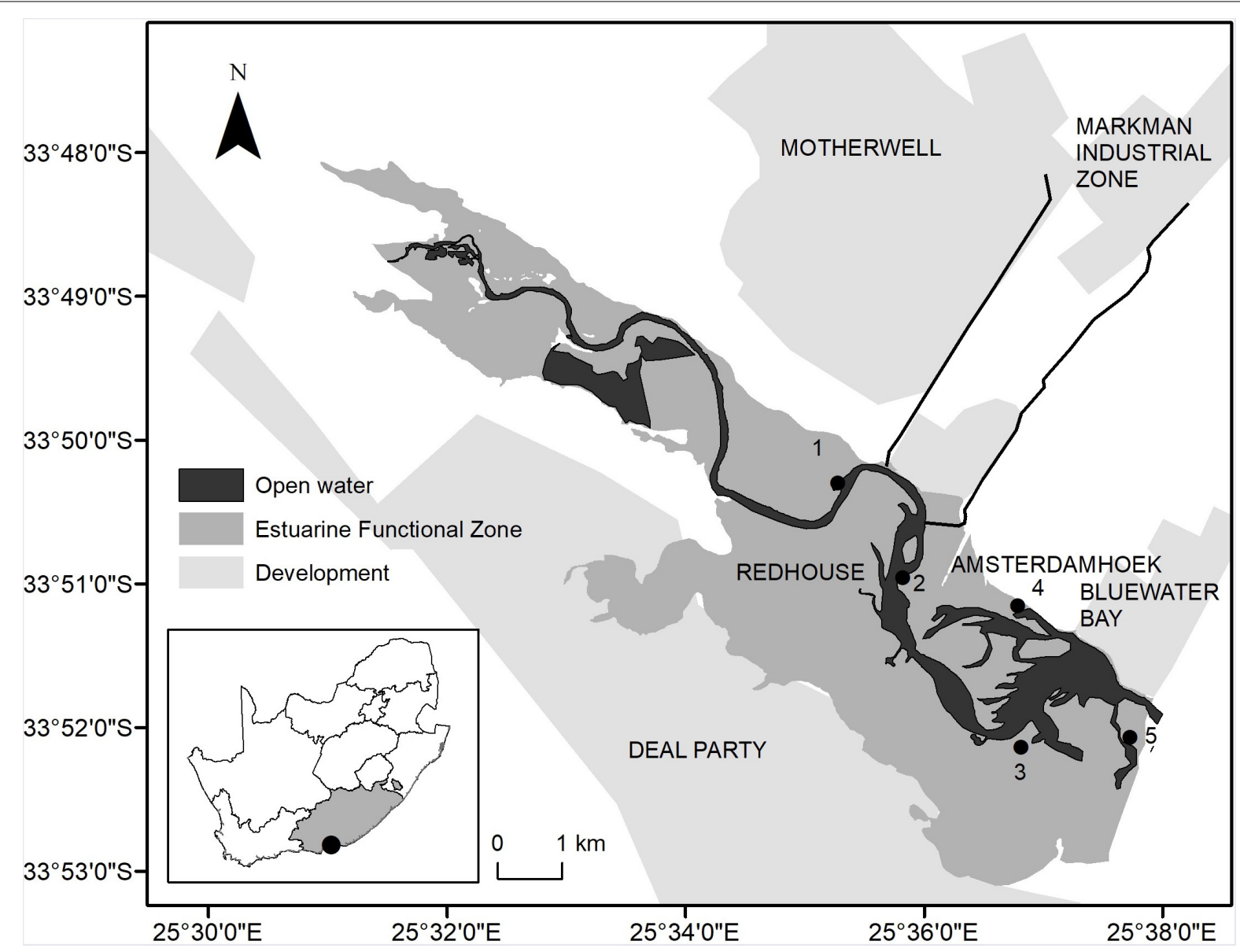

FIGURE 1 | Locations of the sampling sites within the Swartkops Estuary: Motherwell Canal (Site 1), Markman Canal (Site 2), Tiger Bay Launch Site (Site 3), Tipper's Creek (Site 4) and Swartkops Estuary Mouth (Site 5). 
3 is located adjacent to Site 4, on the other side of the estuary, and next to the wastewater treatment works, which treats urban and industrial effluent. A busy national road is located next to Site 3, and can be followed to a dense neighborhood, Amsterdamhoek, adjacent to the riverbank and Tippers Creek (Site 4). The creek contains numerous jetties and a large mudbank. The Swartkops Estuary mouth is predominantly open. The area is subjected to higher flushing rates, due to the strong marine influence in the area, compared to the rest of the estuary. Site 5 is located next to the estuary mouth, where an inactive oyster farm was located. The catchment lacks any large-scale agricultural activities (Bornman et al., 2016).

\section{Metal Determination}

Total metal extractions were performed using a conventional $\mathrm{HNO}_{3}$ (65\%, AR, Merck) digestion in $250 \mathrm{ml}$ glass beakers covered with watch glasses (Du Laing et al., 2003; Phillips et al., 2015). The samples were first freeze-dried using a (Vacutec, V-FD12 Series Freeze Dryer), which dries the sediment at $-60^{\circ} \mathrm{C}$. The homogenized and dry sample of sediment was pushed through a $1 \mathrm{~mm}$ nylon mesh. Then $1.00 \mathrm{~g}$ was digested in $10 \mathrm{ml}$ of the $65 \% \mathrm{HNO}_{3}$ overnight, and afterward on a hotplate for $5 \mathrm{~h}$ at $110^{\circ} \mathrm{C}$. After evaporation to near dryness the sample was diluted with $20 \mathrm{ml}$ of $2 \%\left(\mathrm{v} / \mathrm{v} \mathrm{H}_{2} \mathrm{O}\right)$ nitric acid and transferred to $50 \mathrm{ml}$ volumetric flasks, after filtering with Whatman ${ }^{\circledR}$ glass fiber filters $(\mathrm{GF} / \mathrm{F}$, pore size $=0.7 \mu \mathrm{m})$, and diluted to the mark with Milli-Q ultra-pure water.

Extracts were analyzed for the selected metals using an Inductively Coupled Plasma-Optical Emission Spectrometer (ICP-OES, PerkinElmer ${ }^{\circledR}$, Avio ${ }^{\text {TM }}$ 200) by the aspiration of the sample into an argon generated plasma. The analytical wavelengths used were (in nanometer): Al (396.2), $\mathrm{Cr}$ (357.9), $\mathrm{Cu}$ (224.7), Fe (302.1), Mn (259.4), Ni (221.6), Pb (217.0) and $\mathrm{Zn}$ (206.2). Detection limits for the selected metals (in $\mu \mathrm{g} \mathrm{L}^{-1}$ ) were directly obtained from the ICP-OES program: Al (28), $\mathrm{Cr}$ (23), Cu (7.7), Fe (20), Mn (1.6), Ni (10), Pb (90) and $\mathrm{Zn}$ (5.9). Method blanks were prepared by using the same digestion procedure as the samples and were subtracted from the results during analysis. Blanks and concurrent analysis of standards were used to detect possible contamination during analysis. The samples were measured in triplicate and obtained in ppm. Due to the magnitude of $\mathrm{Al}$ and $\mathrm{Fe}$, they were reported in $\mathrm{mg} \mathrm{g}^{-1}$, whereas the rest of the metals were reported in $\mu \mathrm{gg}^{-1}$.

\section{Sediment Characteristics}

Sediment $\mathrm{pH}$ was measured using a handheld Hanna (Hanna ${ }^{\circledR}$ Instruments, HI98121 Tester) in situ, on the surface sediment, upon collection. All instruments were calibrated and cleaned according to the manufacturer's specifications. Other sediment characteristics were measured in the laboratory; sediment organic content (\%), conductivity $(\mu S)$ and granulometric size. Organic content of the sediment was measured using the loss on ignition method described in Veres (2002) with $10 \mathrm{~g}$ of wet sediment (Eq. 1). The samples were freeze-dried using a (Vacutec, V-FD12 Series Freeze Dryer). Sediment salinity was measured conductometrically by mixing a ratio of $250 \mathrm{~g}$ dried sediment to $100 \mathrm{ml}$ distilled water, or until saturation, according to the specification in Bernard (1990). The mixture was then filtered through Whatman No.1 filter papers and the electrical conductivity was measured using a handheld conductivity meter (CyberScan, HANNA handheld conductivity meter). Granulometric size was also determined with the dry sediment using the sieve method (Wentworth, 1922). All samples were analyzed in triplicate.

$$
\begin{aligned}
\% \mathrm{TOM}= & {[(\text { dry mass before combustion }} \\
& - \text { dry mass after combustion }) / \text { dry mass }] \times 100
\end{aligned}
$$

\section{Statistical Analysis}

The analyses of variance (ANOVA, random effects) was used to test for differences in the total concentrations of metals, the percentage total organic matter (TOM), $\mathrm{pH}$ and salinity. Tukey's post hoc test was then used to compare the means where significant differences were found. The assumptions of normality were verified before analysis with the Shapiro-Wilks test accompanied with the respective histograms. Variables were $\log$ transformed $(\log [\mathrm{M}]$, where $\mathrm{M}$ is the concentration of the selected metal) if the null hypothesis for normality was rejected. Metal enrichment was determined using metal-Al baseline relationships for coastal sediment in the region that included the study site (between the Kromme Estuary and the Sundays Estuary). The regressions were modeled by Newman and Watling (2007). Scatterplots of the metal data were overlain with the straight-line equations provided. Points above the baseline are considered enrichment. Non-metric multidimensional scaling (NMDS) was performed on the metal concentrations and the environmental factors (i.e., the sediment characteristics) were overlain as vectors, to show the degree of influence of the environmental characteristics on the metals and the sites. Statistical processing was performed in RStudio ( $\mathrm{R}$ version 3.5.1 and 4.0.2), a product of RProject using the R-commander (Version 2.6-2) with the packages Vegan, RColorBrewer, Tidyverse and Geoveg.

\section{RESULTS}

\section{Metal Concentrations}

Considering the metal concentration in the sediment, Site 4 had the highest concentrations of metals in the sediment with no exceptions, followed by Site 3 (Table 1). The lowest concentrations were measured in Site 5, with the exception of $\mathrm{Zn}$, where the lowest value occurred in Site 1. These differences were for the most cases significant $(p<0.05)$, however, $\mathrm{Zn}$ concentrations had no statistical difference across all the sites. Other cases where Site 5 did not contain the statistically lowest concentration was: $\mathrm{Cr}$ and $\mathrm{Cu}$ (Site 1 and Site 2; $p>0.05$ ), and Mn (Site $1 ; p>0.05$ ) Contrastingly, the metal normalizer (Al), showed statistical differences across all sites with the exception of Site 2 and Site $3(p>0.05)$. 
TABLE 1 | Average metal concentrations (Al, Fe = mean $\mathrm{mg} \mathrm{g}^{-1} \pm \mathrm{SD}$; Cr, Cu, Mn, Ni, Pb, Zn $=$ mean $\mu \mathrm{g} \mathrm{g}^{-1} \pm \mathrm{SD}$ ) of the surface sediment at the sampling sites $(N=15)$.

\begin{tabular}{|c|c|c|c|c|c|}
\hline [M] & Site 1 & Site 2 & Site 3 & Site 4 & Site 5 \\
\hline $\mathrm{Al}$ & $8.8 \pm 0.2^{a}$ & $15.1 \pm 0.3^{b}$ & $20.3 \pm 6.4^{b}$ & $42.1 \pm 2.8^{C}$ & $2.1 \pm 0.2^{d}$ \\
\hline $\mathrm{Fe}$ & $18.1 \pm 6.3^{a}$ & $24.8 \pm 1.4^{a}$ & $30.2 \pm 7.1^{a}$ & $58.0 \pm 4.6^{b}$ & $5.1 \pm 0.9^{c}$ \\
\hline $\mathrm{Cr}$ & $21.7 \pm 5.6^{a}$ & $26.6 \pm 0.3^{a, c}$ & $42.3 \pm 15.0^{a}$ & $99.4 \pm 2.2^{b}$ & $14.1 \pm 2.5^{c}$ \\
\hline $\mathrm{Cu}$ & $36.9 \pm 7.1^{a, c}$ & $39.7 \pm 3.9^{a, c}$ & $52.0 \pm 9.1^{a}$ & $85.6 \pm 7.6^{b}$ & $18.4 \pm 3.0^{c}$ \\
\hline $\mathrm{Mn}$ & $110.9 \pm 55.6^{a, c}$ & $283.1 \pm 34.3^{a, b}$ & $286.6 \pm 49.4^{a, b}$ & $379.1 \pm 103.1^{b}$ & $33.9 \pm 0.3^{c}$ \\
\hline $\mathrm{Ni}$ & $10.3 \pm 2.7^{a}$ & $10.5 \pm 0.7^{a}$ & $14.7 \pm 3.3^{a}$ & $24.4 \pm 1.8^{b}$ & $2.5 \pm 0.3^{c}$ \\
\hline $\mathrm{Pb}$ & $48.3 \pm 12.9^{a}$ & $60.8 \pm 2.8^{a}$ & $89.3 \pm 27.1^{a}$ & $187.5 \pm 19.1^{b}$ & $14.8 \pm 1.8^{c}$ \\
\hline $\mathrm{Zn}$ & $90.9 \pm 20.5^{a}$ & $93.4 \pm 4.9^{a}$ & $104.5 \pm 24.9^{a}$ & $136.6 \pm 16.0^{a}$ & $98.6 \pm 23.2^{a}$ \\
\hline
\end{tabular}

Different letters $(a, b, c, d)$ indicate significant differences between values of the same element within the five sites ( $p<0.05)$.

\section{Sediment Characteristics}

Figure $2 \mathrm{~A}$ show the separation of the metal concentrations in Site 5 to the rest of the sites. The NMDS showed a good fit with a stress value $<0.05$. Similarities occurred between Site 2 and Site 3, seen by the overlap of the diagram in the figure. The sediment characteristics had different degree of influence on the metal concentrations in the sites. Gravel, $\mathrm{pH}$ and organic matter showed significant results $(p<0.05)$. The environmental vector representing percentage gravel showed the greatest influence in Site 1, while $\mathrm{pH}$ and total organic matter showed the greatest influence in Site 2 and Site 3. The metal concentrations all differed from each other (Figure 2B), but according to the environmental vectors do not point directly at the type of metals. The exception is $\mathrm{Mn}$, where the significant vector, total organic matter, is directed to it.

Total organic matter (TOM) was highest at Site 3 $(6.32 \pm 0.008 \%)$ and the lowest at Site $5(2.89 \pm 0.003 \%$; Figure 3). These sites also displayed the highest $(41.53 \%)$ and lowest $(1.40 \%)$ silt/clay content, respectively. The difference was significant according to statistical processing $(p<0.05)$. The other sites displayed no significant statistical differences in TOM. The grain size distribution was reasonably similar throughout the sites except for Site 3 and Site 5. The latter having a much coarser grain than the other sites. Gravel was not present in Site 1 and Site 2 and was negligible in Site 4 and Site $5(<0.1 \%)$. Site 3 had the highest gravel content but did not exceed $2 \%$.

The $\mathrm{pH}$ differed across the sites (Figure $\mathbf{4 A}$ ). The lowest $\mathrm{pH}$ was found in Site $4(7.3 \pm 0.1)$, while the highest was in Site $5(8.3 \pm 0.1)$ and they differed significantly from each other $(p<0.001)$. The $\mathrm{pH}$ of Site 4 was also lower than Site 2 and Site 3 $(p<0.05)$, and Site 5 had a higher $\mathrm{pH}$ than Site $1(p<0.05)$. The salinity ( $\mu S$; Figure 4B) did not differ significantly between sites according to statistical testing. The lowest salinity was measured in Site $1(6.6 \pm 0.9)$, while the highest in Site 2 and Site 4 $(10.8 \pm 0.6$ and $10.8 \pm 1.3$; Figure 4).

\section{Metal Contamination}

The majority of the metals are higher than the baseline (Figure 5). $\mathrm{Cu}, \mathrm{Cr}, \mathrm{Fe}, \mathrm{Pb}$, and $\mathrm{Zn}$ show enrichment across all the sites. $\mathrm{Cr}$ is notably much higher than the baseline in Site 4 compared to the other sites and does not follow the trend of the baseline (Figure 5B). $\mathrm{Cu}, \mathrm{Pb}$, and Fe plots deviate from the gradients of the baseline, indicating that the metal concentration increases more steeply with the metal normalizer, than the baseline suggested (Figures 5A-C). The majority of the points fall above the baseline for $\mathrm{Mn}$ and $\mathrm{Ni}$ however, the exceptions occur in Site 1 and Site 4 for $\mathrm{Mn}$ and Site 4 for $\mathrm{Ni}$ (Figures 5D,E). The plots for the latter metal, Ni follows the baseline closely.

\section{DISCUSSION}

This study measured six of the most common metal contaminants in the Swartkops Estuary i.e., $\mathrm{Al}, \mathrm{Cr}, \mathrm{Pb}$, $\mathrm{Mn}, \mathrm{Ni}$ and $\mathrm{Zn}$ (Strawn et al., 2015). The average metal concentrations in this study follows a decreasing order of $\mathrm{Fe}>\mathrm{Al}>\mathrm{Mn}>\mathrm{Zn}>\mathrm{Pb}>\mathrm{Cu}>\mathrm{Cr}>\mathrm{Ni}($ Table 1). The five sites within the estuary showed a $46 \%$ average increase in metal concentrations $(\mathrm{Cr}, \mathrm{Cu}, \mathrm{Mn}, \mathrm{Pb}, \mathrm{Zn})$ over the past 23 years (Binning and Baird, 2001). The same study compared the 1996 dataset with another in 1979, and found an average increase of $149 \%$ in metal concentrations between them. Previous authors agree that the anthropogenic activities surrounding the estuary are to blame for the increases (Baird et al., 1986; Binning and Baird, 2001; Phillips et al., 2015). However, metals also occur naturally in the sediment due to the weathering of rock (Kabata-Pendias, 2011). Some metals such as $\mathrm{Al}$ and $\mathrm{Fe}$, form a large part of the sediment matrix, and occur in much higher concentrations that the other metals (Newman and Watling, 2007). The $\mathrm{Al}$ and $\mathrm{Fe}$ concentrations ranged from 2.1-42.1 $\mathrm{mg} \mathrm{g}^{-1}$ to $5.1-58.0 \mathrm{mg} \mathrm{g}^{-1}$ (Table 1), respectively. Newman and Watling (2007) established that Fe contamination is prevalent in the Swartkops Estuary. The $\mathrm{Al}$ concentrations measured in this study were of a comparable range to previous studies (0-40 $\mathrm{mg} \mathrm{g}^{-1}$ ), which also confirms that no significant $\mathrm{Al}$ contamination has occurred in the middle and lower reaches of the estuary (Watling and Watling, 1979, 1982; Newman and Watling, 2007). Gyedu-Ababio (2011) reported much lower Fe concentrations in the sediment of the Swartkops Estuary (1.9 $\mathrm{mg} \mathrm{g}^{-1}-16.42 \mathrm{mg} \mathrm{g}^{-1}$ ), but is still comparable where sites correspond. Manganese concentrations ranged from 33.9 to $379.1 \mu \mathrm{g} \mathrm{g}^{-1}$ in this study. Iron and $\mathrm{Mn}$ oxides play an important role in scavenging other metals such as $\mathrm{Cu}, \mathrm{Ni}, \mathrm{Pb}$ and Zn from solution (Vesper, 2012). Gyedu-Ababio (2011) also found Mn concentrations between 64 and $229 \mu \mathrm{g} \mathrm{g}^{-1}$, 


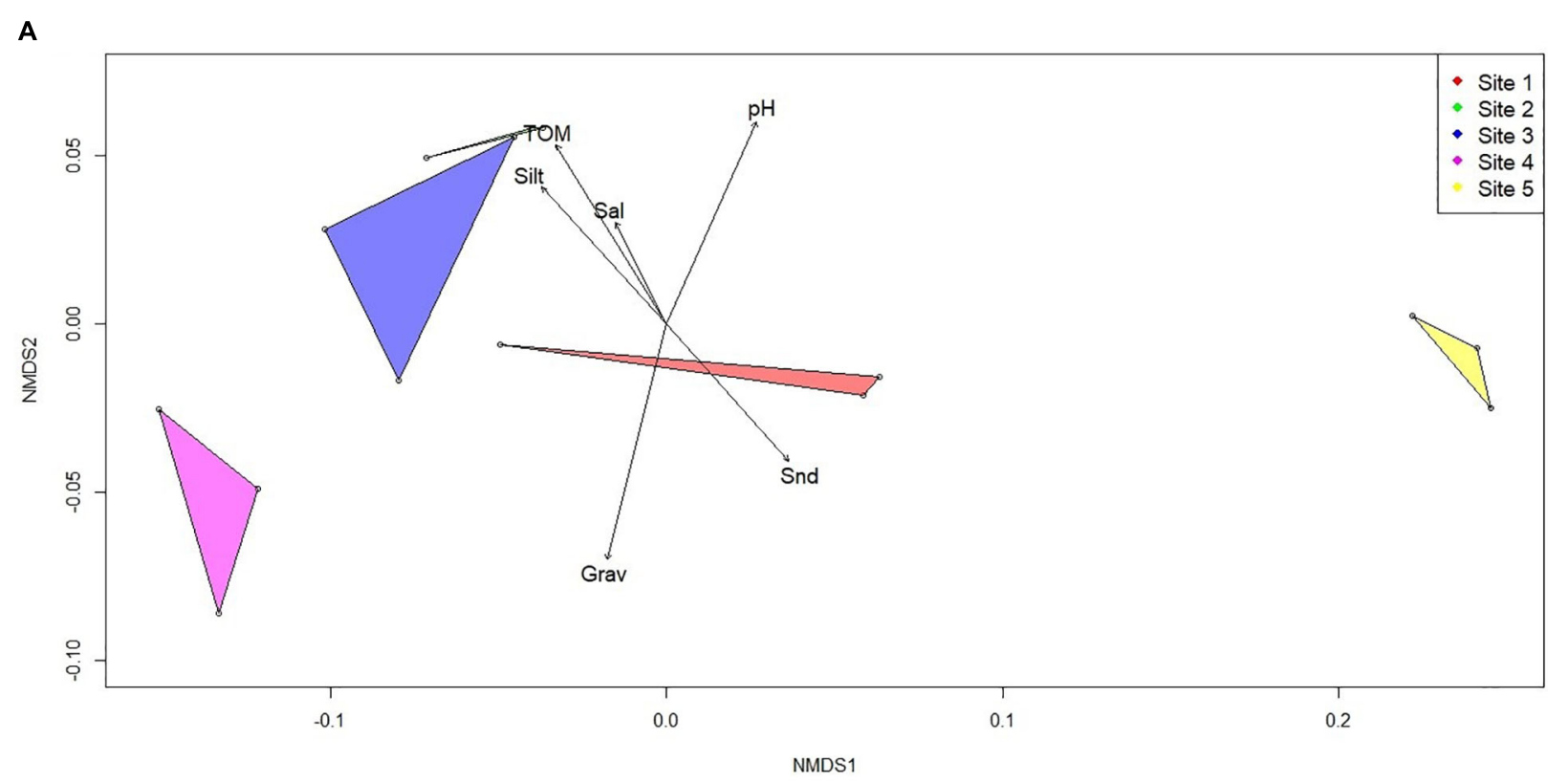

B

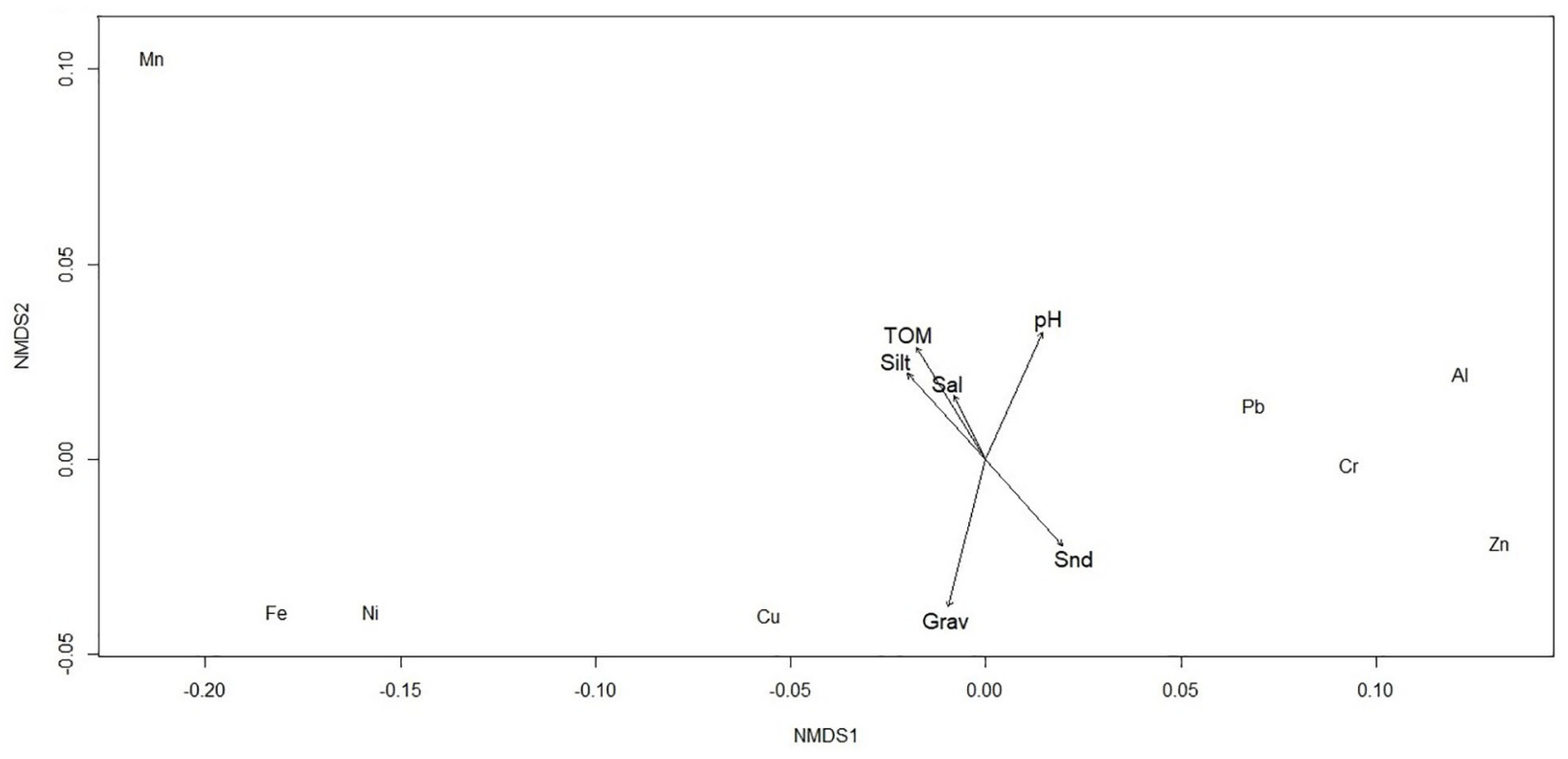

FIGURE 2 | NMDS of (A) metal concentration per site and (B) metal concentrations per metal type with an overlay of the sediment characteristics (where: TOM, Total Organic Matter; Sal, salinity; Silt, percentage silt and clay; Snd, percentage sand; Grav, percentage gravel, and pH).

previously in the estuary. The concentrations reported by this author are also lower for $\mathrm{Mn}$, but is again comparable where the sites correspond.

Lead concentrations in this study ranged from 14.8 to $187.5 \mu \mathrm{g} \mathrm{g}^{-1}$ of sediment, showing a $47 \%$ increase from 1996 (Table 1). High loads of $\mathrm{Pb}$ were associated with the stormwater originating from high density, low-income settlements in entering False Bay, South Africa (MacKay, 1994). This may be the case in the Swartkops Estuary, as stormwater and effluent from the Wastewater Works enters the system. Another source of $\mathrm{Pb}$ contamination is the highway, as automobile exhaust gas is a well-known source of $\mathrm{Pb}$ aerosol (Mielke et al., 2010). Site 4 was the only site in which $\mathrm{Pb}$ concentrations exceeded $\mathrm{Zn}$ concentrations-owed to its proximity to an urban roadway. Lead concentrations in this study were much higher than that reported by Phillips et al. (2015)-maximum concentrations differed by approximately $60 \mathrm{\mu g} \mathrm{g}^{-1}$ (or 16\%) of sediment. In both these cases, the maximum concentrations were located close 


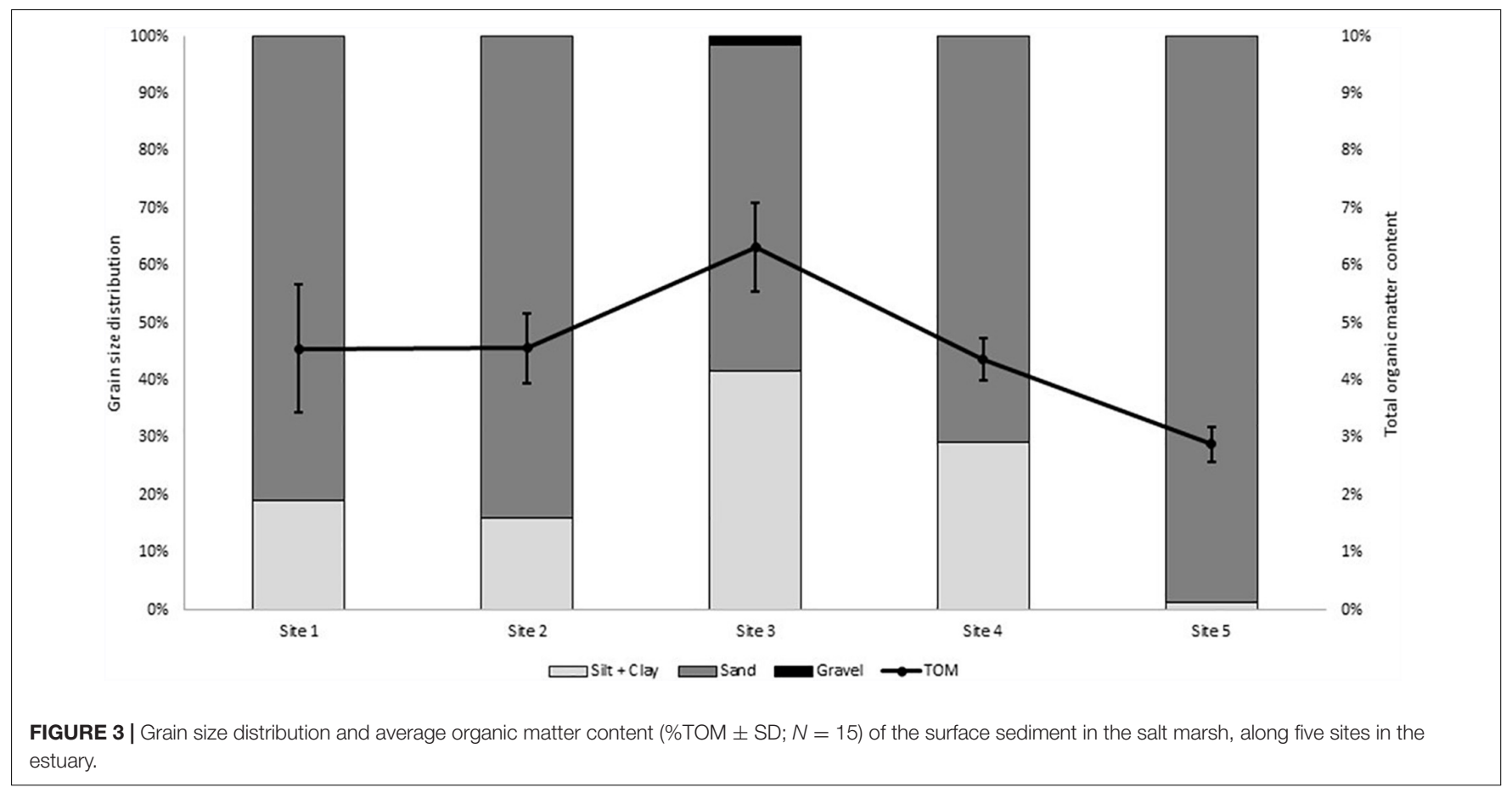

to highways and roads, that is; Redhouse and Tippers Creek (Site 4; Figure $\mathbf{1}$ and Table 1). Copper, $\mathrm{Pb}, \mathrm{Ni}$ and $\mathrm{Zn}$ are the most commonly measured metals in the estuary. Copper and $\mathrm{Zn}$ concentrations ranged from $18.4-85.6 \mu \mathrm{g} \mathrm{g}^{-1}$ to 93.4$136.6 \mu \mathrm{g} \mathrm{g}^{-1}$. Binning and Baird (2001) indicated that $\mathrm{Cu}$ and $\mathrm{Zn}$ pollution enters the system in the freshwater reaches, from the industries in Uitenhage (Figure 1). Phillips et al. (2015) found their highest $\mathrm{Cu}$ and $\mathrm{Zn}$ concentrations $\left(51.5 \mu \mathrm{g} \mathrm{g}^{-1}\right.$ and $112.9 \mathrm{\mu g} \mathrm{g}^{-1}$, respectively) in the Upper Markman Canal, which carries effluent from industries into the estuary.

There are multiple point sources in the Swartkops Estuary, and most prominent is the effluent from the Markman (industrial) Canal, the stormwater from the Motherwell Canal, treated effluent from the Fishwaterflats Wastewater Treatment Works, and contaminated water from the Papenkuils River. However, the data indicates that the highest metal concentrations were measured in Site 4 (Tippers Creek), which is downstream from the two point-sources mentioned first. Site 3, also downstream from the two main point sources, contained the second highest metal concentrations in the estuary. The Papenkuils River connects to the Swartkops Estuary at this site. Watling and Emmerson (1981) found higher concentrations of $\mathrm{Cu}, \mathrm{Zn}, \mathrm{Cr}$ and $\mathrm{Pb}$ in the Papenkuils than in the estuary. Both sites are located within creeks and between two motorway bridges, that carry heavy traffic. The bridges are one of the factors that cause heavy sediment accretion in Site 3 and Site 4 (Esterhuysen and Rust, 1987). Sediment accretion in Site 4 is further enhanced by the jetties, which also trap sediment and creates a large sand bank against the concrete wall, adjacent to the urban area, Amsterdamhoek (Figure 1). The obstructed flow of water entering the creek is therefore trapped between the artificial concrete bank with the jetties and the large sand bank in the middle of the estuary. According to Esterhuysen and Rust (1987), both Site 3 and Site 4 are conducive to trapping sediment and other particles that flow downstream. These conditions make the sites favorable to trap particles containing metals, as well as capturing soluble metals from the overlaying water column. The extensive root system of $S$. tegetaria can also trap sediment particles that flow down river, creating an ideal environment to act as a metal sink. The metals trapped within the creeks may most likely originate from the Motherwell Canal and the Markman Canal, which transports effluent from lowincome settlements and large industries, respectively. Indeed, Watling and Watling (1982) and Nel et al. (2015) both formed the conclusion that pollutants transported into Tippers Creek (Site 4) may be incompletely flushed by tidal action and may have resulted in its build-up over time. Adams et al. (2019) recommended Tippers Creek as a long-term metal monitoring site.

Each of the five sites sampled in the estuary show distinct differences, and general similarities (Figure 2A). Metal concentrations in Site 2 and Site 3 are the most similar, depicted by the overlap in Figure 2A. Site 4 is distinctly dissimilar from Site 2 and Site 3, just emphasizing the extremely high metal concentrations found here. The lowest metal concentrations in Site 5 can also distinctly be seen, as the diagram is far removed from the other sites. The sediment characteristics of the given sites largely affect the capacity of the sediment to accumulate metals. Contrastingly, it also dictates the potential for leaching (or flushing) and the bioavailability (or mobility) of the metal to plants and other biota. Authors are still debating which sediment characteristics are the most important determinant of the element's form (Kabata-Pendias, 2011), however, pH, carbonates and $\mathrm{Fe}$ and $\mathrm{Mn}$ oxides greatly influence the behavior 
A

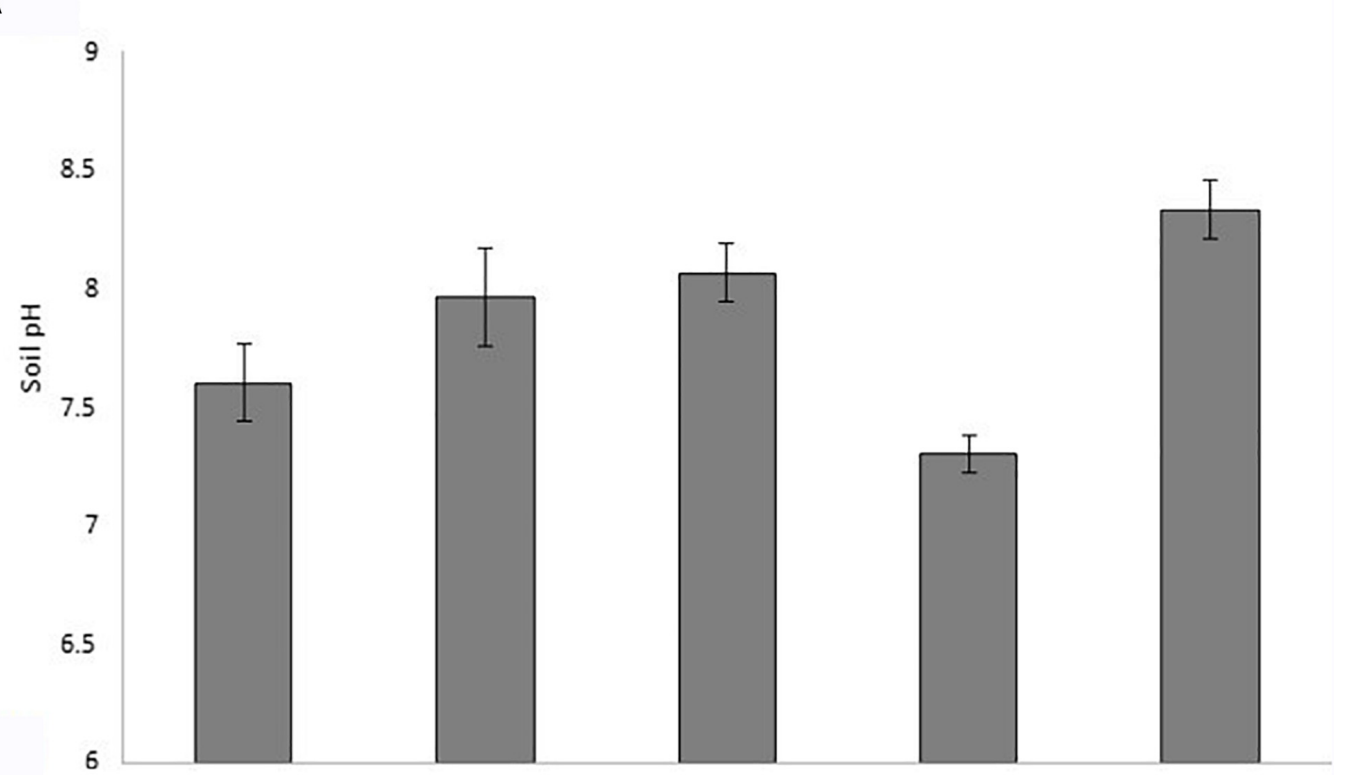

B

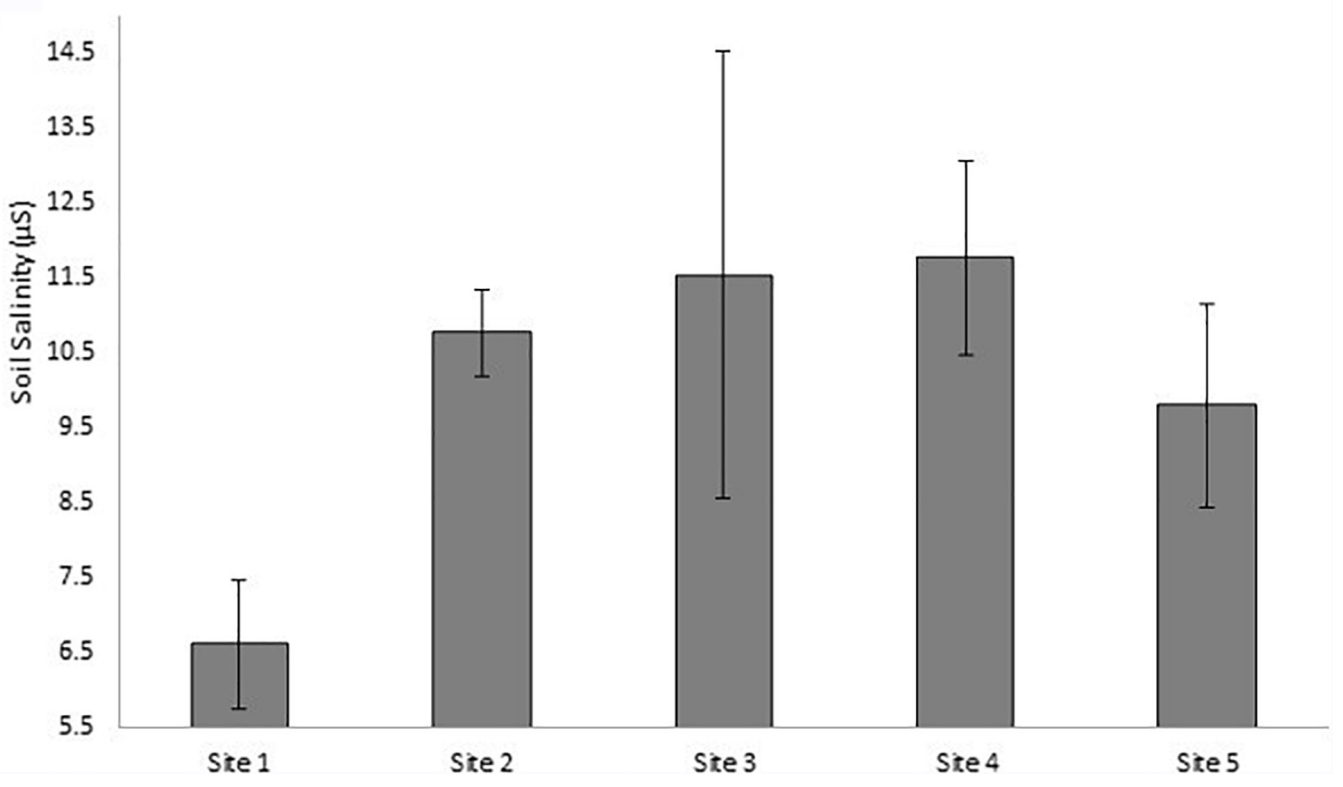

FIGURE 4 | Average sediment $\mathrm{pH}$ and salinity $(\mu \mathrm{S})$ at each of the five sites, of the surface sediment in the salt marsh, with error bars $( \pm \mathrm{SD} ; N=15)$.

of chemical elements (Shine et al., 1995; Li et al., 2013). Others suggest that it is $\mathrm{pH}$, redox potential and organic matter that are the most important in sediments (Hermann and Neumannmahlkau, 1985; Strawn and Sparks, 2000). In this study, the gravel content, $\mathrm{pH}$ and organic matter content had the most significant effect on the metal behavior. Copper and $\mathrm{Pb}$ did not form a close association with the total organic matter content as would be expected (Figure 2B; Duarte et al., 2010; Wyatt and Stevenson, 2010; Human et al., 2020), but metal behavior in sediment is complex, and the other characteristics and unmeasured factors cannot be ignored. The pattern of the environmental vectors in Figure 2B would suggest that the sediment characteristics play a dynamic part in the metal form.
The study sites are dominated by the larger grain sizes, sand (Avg\% sand > 50\%; Figure 3). Bradley and Morris (1990), who studied salt marshes across the Eastern United States of America, also found that the salt marshes tend to be dominated by sand. This agrees with previous assessments of the middle and lower reaches of the Swartkops Estuary (Reddering et al., 1981; Els, 2020). Reddering et al. (1981) indicated that the sand originates by tidal transportation from the sea. Large grain size (sand) in sediments usually present lower levels of metal accumulation (Williams et al., 1994; Zhang et al., 2001). Contrastingly, higher percentages of the finer particles (clays and silt), increases the metal binding capacity of cationic metals onto the negatively charged surfaces (Ujeviæ et al., 2000). The binding capacity of 

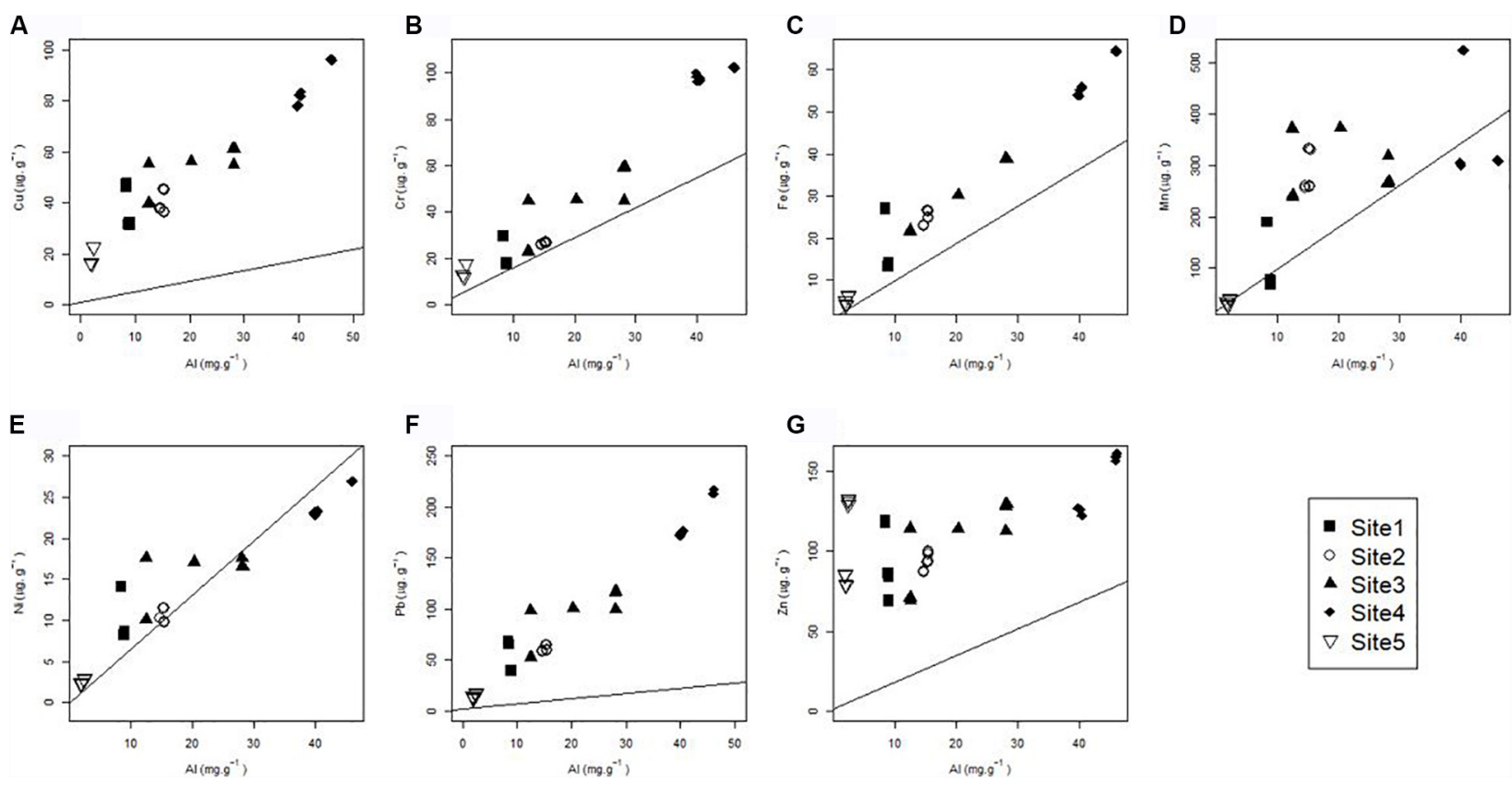

FIGURE 5 | Total individual metal content (A) Cu, (B) Cr, (C) Fe, (D) Mn, (E) Ni, (F) Pb and (G) Zn against the concentration of the metal normalizer (Al), in the surface sediment colonized by $S$. tegetaria. The scatterplot represents the different metal concentrations per site and is overlain with the linear models created by Newman and Watling (2007).

smaller sediment particles are so significant due to the high specific surface area creating more binding sites for metals (Lin et al., 2003). In this study, the estuary mouth (Site 5) had the highest sand content at 97\%, while Site 3 had lowest at 57\% followed by Site 4 at $82 \%$ (Figure 3). Site 3 and Site 4 contained the only silt and clay content above $17 \%$; that is 41.5 and $33.8 \%$, respectively (Figure 3). This may indicate a higher degree of fluvial sediment in-put in at these sites, previously established as trapping sediment and other particles flowing downstream. High sand content in the estuary increases the potential of metals to be leached to the water column and transported downstream. This may occur in Site 1 and Site 2 (\% sand >80\%), where two of the point sources occur (Motherwell Canal and Markman Canal). The metals may thereafter be captured and accumulated by the higher silt/clay content in Site 3 and Site 4.

The organic content of sediments in this study is very low but followed a similar pattern as the grain sizes. The highest value is $6.3 \%$ at Site 3 and the lowest value is $2.9 \%$ at Site 5 (Estuary Mouth). The organic matter content in Site 4 fell just below the average at 4.4\%. Bradley and Morris (1990) indicated that these values are natural, as they found organic matter ranges from 2 to $16 \%$ in salt marshes. A recent study in the Swartkops Estuary found similar organic matter content (Els, 2020). Organic matter plays a significant role in metal accumulation. Low organic matter content in sediments usually presents lower levels of metal accumulation (Williams et al., 1994). Higher percentages of organic matter increases the metal binding capacity of cationic metals by forming insoluble complexes with the metals (Ujeviæ et al., 2000). Copper and $\mathrm{Pb}$ in general prefer to bind to sediment organic matter, creating complexes with the humic acids that form part of sediment organic matter (Duarte et al., 2010; Wyatt and Stevenson, 2010; Human et al., 2020). Although, $\mathrm{Cu}$ and Pb's association with sediment organic matter is strong, other metals also form bonds with it due to the high specific surface area provided by the sediment organic matter (Lin et al., 2003).

Lastly, the $\mathrm{pH}$ and salinity in the rhizosediment of the salt marsh ranged between 7.3-8.3 and 6.6-11.8 $\mu \mathrm{S}$, respectively (Figure 4). The highest $\mathrm{pH}$ was found at the mouth (Site 5) and the lowest at Site 4, though the latter is not quite acidic. Acidity increases the mobility of cationic metals-creating conditions conducive to the leaching of these metals into the water column (Williams et al., 1994). It is due to the adsorption and desorption mechanisms onto sediment surfaces that are largely controlled by $\mathrm{pH}$ (Li et al., 2013). However, Eh (redox potential) also has an important relationship with metal mobility, and in cases where $\mathrm{pH}$ is alkaline and $\mathrm{Eh}$ is highly positive, metals can become immobile before reverting to a mobile anionic metal species (Hermann and Neumannmahlkau, 1985; Kabata-Pendias, 2011). The $\mathrm{pH}$ requirements to form an ionic $\mathrm{Cu}$ species $\left(\mathrm{Cu}_{2} \mathrm{O}_{2}{ }^{2-}\right)$ is above 12 and did not occur in this dataset (Hermann and Neumann-mahlkau, 1985). The salinity remained fairly constant within the sites, however, Site 1, being the uppermost site showed significantly lower salinity. Fritioff et al. (2005) found that metals become more bioavailable for submersed plants (like S. tegetaria) with decreasing salinity and increasing temperature. Lower salinity and high sand content in upper sites, close to the point sources (Motherwell Canal and Markman Canal), creates conditions that enhance metal mobility, and therefore its transport to the lower reaches of the estuary. 
For this study, the baseline models indicate that all the sites are metal enriched-where metal concentrations fall above the baseline (Figure 5). The exceptions are for Mn (Site 4 and Site 1), and $\mathrm{Ni}$ in Site 4 and Site 2 (Figures 5D,E). Copper, $\mathrm{Pb}$ and $\mathrm{Zn}$ in particular show high enrichment throughout all the sites, with the exception of $\mathrm{Pb}$, which had low concentrations at the mouth (Figures 5A,F,G). The sites with the highest concentrations, Site 3 and Site 4, show anomalous $\mathrm{Cu}, \mathrm{Cr}, \mathrm{Fe}, \mathrm{Pb}$ and $\mathrm{Zn}$ levels. The mouth (Site 5), which contained the lowest metal concentrations, show enrichment in $\mathrm{Cu}, \mathrm{Cr}, \mathrm{Fe}, \mathrm{Ni}, \mathrm{Pb}$ and $\mathrm{Zn}$. Some of these data points fall close to the baseline, which may indicate that the enrichment in Site 1 is not that large, however, $\mathrm{Cu}$ and $\mathrm{Zn}$ are of particular concern (Figures 5A,G). An outfall, located $1 \mathrm{~km} \mathrm{SSW}$ from the estuary mouth is a source of contamination, and waste is transported to Site 5 through the connected bay (Emmerson et al., 1983). The outfall contains treated urban and industrial effluent from the wastewater treatment works. However, with the presence of sediment characteristics conducive to leaching and the marine turbulence at the mouth, the contamination at the mouth has not reached critical levels. The same cannot be said for the middle and lower reaches (Site 1-Site 4) that have metal concentrations far exceeding the baseline.

\section{CONCLUSION}

This study investigated the levels of metal contamination within the salt marsh habitat of the Swartkops Estuary. From the baseline models it is clear that the pollution is of anthropogenic origin and the estuary is highly enriched by metal contamination resulting from the vast array of urban and industrial settlements, which releases effluent into the estuary. It follows that the gravel content, $\mathrm{pH}$ and organic matter content had the most significant effect on the metal behavior. Considering the above observations, it can be concluded that the rhizosediment of $S$. tegetaria acts as a metal sink and localizes the contamination of metals to a large extent thereby performing an important ecosystem service.

\section{REFERENCES}

Adams, J. B. (2020). Salt marsh at the tip of Africa: patterns, processes and changes in response to climate change. Estuar. Coast. Shelf Sci. 237:106650. doi: 10.1016/j.ecss.2020.106650

Adams, J. B., Pretorius, L., and Snow, G. C. (2019). Deterioration in the water quality of an urbanised estuary with recommendations for improvement. Water SA 45, 86-96. doi: 10.4314/wsa.v4 $5 \mathrm{i} 1.10$

Almeida, C. M. R., Mucha, A. P., Bordalo, A. A., and Vasconcelos, M. T. S. D. (2008). Influence of a salt marsh plant (Halimione portulacoides) on the concentrations and potential mobility of metals in sediments. Sci. Total Environ. 403, 188-195. doi: 10.1016/j.scitotenv.2008. 05.044

Baird, D., Hanekom, N., and Grindley, J. (1986). "Report No. 23: swartkops (CSE 3)," in Estuaries of the Cape, Part 2: Synopsis of Available Information Individual Systems.CSIR Research Report No. 422, eds A. E. F. Heydorn and J. R. Grindley (New Delhi: CSIR).

Barbier, E. B., Hacker, S. D., Kennedy, C., Koch, E. W., Stier, A. C., and Silliman, B. R. (2011). The value of estuarine and coastal ecosystem services. Ecol. Monogr. 81, 169-193. doi: 10.1890/101510.1
Management practices are crucial at this stage of development as high concentrations of metals leading to metal enrichment can restrict some recreational activities, in and around the estuary.

\section{DATA AVAILABILITY STATEMENT}

The raw data supporting the conclusions of this article will be made available by the authors, without undue reservation.

\section{AUTHOR CONTRIBUTIONS}

MN wrote the article and did the laboratory analysis. MN and $\mathrm{LH}$ contributed to the field analysis, while the latter also conceptualized the research. LH, JA, MN, and GR provided conceptual and editorial inputs on the manuscript and discussed field methodology. All authors contributed to the article and approved the submitted version.

\section{FUNDING}

MN was supported by a scholarship from the National Research Foundation of South Africa (Grant Number: 116920). This work was supported by the Shallow Marine and Coastal Research Infrastructure (SMCRI) platform hosted by the South African Environmental Observation Network Elwandle Node (SAEON). The publication fees for this article was paid for by NRF Incentive Funding (Grant Number: 119449).

\section{ACKNOWLEDGMENTS}

The authors wish to thank the Shallow Water Ecosystem research group (funded by UID 84375DSI/NRF Research Chair) for assistance in the laboratory and field.

Basta, N. T., Ryan, J. A., and Chaney, R. L. (2005). Trace element chemistry in residual-treated soil: key concepts and metal bioavailability. J. Environ. Qual. 34, 49-63. doi: 10.2134/jeq2005.0049dup

Bernard, R. O. (1990). Handbook of Standard Soil Testing Methods for Advisory Purposes. Pretoria: Sediment Science Society of South Africa.

Binning, K., and Baird, D. (2001). Survey of heavy metals in the sediments of the Swartkops River Estuary, Port Elizabeth South Africa. Water SA 27, 461-466. doi: 10.4314/wsa.v27i4.4958

Bonanno, G., Borg, J. A., and Di Martino, V. (2017). Levels of heavy metals in wetland and marine vascular plants and their biomonitoring potential: a comparative assessment. Sci. Total Environ. 576, 796-806. doi: 10.1016/j. scitotenv.2016.10.171

Bonanno, G., Vymazal, J., and Cirelli, G. L. (2018). Translocation, accumulation and bioindication of trace elements in wetland plants. Sci. Total Environ. 631-632, 252-261. doi: 10.1016/j.scitotenv.2018.03.039

Bornman, T. G., Schmidt, J., Adams, J. B., Mfikili, A. N., Farre, R. E., and Smit, A. J. (2016). Relative sea-level rise and the potential for subsidence of the Swartkops Estuary intertidal salt marshes, South Africa. S. Afr. J. Bot. 107, 91-100. doi: 10.1016/j.sajb.2016.05.003

Bradley, P., and Morris, J. (1990). Physical characteristics of salt marsh sediments: ecological implications. Mar. Ecol. Prog. Ser. 61, 245-252. doi: 10.3354/ meps061245 
Brown, C. E., and Rajkaran, A. (2020). Biomass partitioning in an endemic southern African salt marsh species Salicornia tegetaria (Chenopodiaceae). Afr. J. Aquat. Sci. 45, 41-48. doi: 10.2989/16085914.2019. 1687419

Caçador, I., Caetano, M., Duarte, B., and Vale, C. (2009). Stock and losses of trace metals from salt marsh plants. Mar. Environ. Res. 67, 75-82. doi: 10.1016/j. marenvres.2008.11.004

Carrillo -Gonzalez, R., Simunek, J., Sauve, S., and Adriano, D. (2006). Mechanisms and pathways of trace element mobility in soils. Adv. Agron. 91, 111-178. doi: 10.1016/S0065-2113(06)91003-7

Colloty, B. M., Adams, J. B., and Bate, G. C. (2000). The use of a botanical importance rating to assess changes in the flora of the Swartkops Estuary over time. Water SA 26, 171-180.

Crane, R. A., Sinnett, D. E., Cleall, P. J., and Sapsford, D. J. (2017). Physicochemical composition of wastes and co-located environmental designations at legacy mine sites in the south west of England and Wales: implications for their resource potential. Resour. Conserv. Recycl. 123, 117-134. doi: 10.1016/j. resconrec.2016.08.009

Douglas, G. B., and Adeney, J. A. (2000). Diagenetic cycling of trace elements in the bottom sediments of the Swan River Estuary, Western Australia. Appl. Geochem. 15, 551-566. doi: 10.1016/S0883-2927(99)00070-0

Doyle, M. O., and Otte, M. L. (1997). Organism-induced accumulation of iron, zinc and arsenic in wetland soils. Environ. Pollut. 96, 1-11. doi: 10.1016/S02697491(97)00014-6

Du Laing, G., Tack, F. M. G., and Verloo, M. G. (2003). Performance of selected destruction methods for the determination of heavy metals in reed plants (Phragmites australis). Anal. Chim. Acta 497, 191-198. doi: 10.1016/j.aca.2003. 08.044

Duarte, B., Caetano, M., Almeida, P. R., Vale, C., and Caçador, I. (2010). Accumulation and biological cycling of heavy metal in four salt marsh species, from Tagus estuary (Portugal). Environ. Pollut. 158, 1661-1668. doi: 10.1016/j. envpol.2009.12.004

Els, J. (2020). Carbon and Nutrient Storage of the Swartkops Estuary Salt Marsh and Seagrass Habitats. Port Elizabeth: Nelson Mandela University.

Emmerson, W. D., McLachlan, A., Watling, H. R., and Watling, R. J. (1983). Some ecological effects of two sewrage outfalls in Algoa Bay. Water SA 9, 23-30.

Esterhuysen, K., and Rust, I. C. (1987). Channel migration in the lower Swartkops estuary. S. Afr. J. Sci. 83, 521-525.

Forstner, U., and Wittman, G. T. W. (1981). Metal Pollution in the Aquatic Environment. Berlin: Springer-Verlag.

Fritioff, ̊̊, Kautsky, L., and Greger, M. (2005). Influence of temperature and salinity on heavy metal uptake by submersed plants. Environ. Pollut. 133, 265-274. doi: 10.1016/j.envpol.2004.05.036

Gyedu-Ababio, T. K. (2011). Pollution status of two river estuaries in the Eastern Cape, South Africa, based on benthic meiofauna analyses. J. Water Resour. Prot. 3, 473-486. doi: 10.4236/jwarp.2011.37057

Hermann, R., and Neumann-mahlkau, P. (1985). The mobility of zinc, cadmium, copper, lead, iron and arsenic in ground water as a function of redox potential and pH. Sci. Total Environ. 43, 1-12. doi: 10.1016/0048-9697(85)90027-0

Human, L., Feijão, E., de Carvalho, R. C., Caçador, I., Reis-Santos, P., Fonseca, V., et al. (2020). Mediterranean salt marsh sediment metal speciation and bioavailability changes induced by the spreading of non-indigenous Spartina patens. Estuar. Coast. Shelf Sci. 243:106921. doi: 10.1016/j.ecss.2020.106921

Impellitteri, C. A., Allen, H. E., Yin, Y., You, S. J., and Saxe, J. K. (2001). “Soil properties controlling metal partitioning," in Heavy Metals Release in Soils, eds H. M. Selim and D. L. Sparks (New York, NY: Lewis Publishers), 149-165. doi: 10.1201/9781420032611.ch7

Kabata-Pendias, A. (2011). Trace Elements in Soils and Plants, 4th Edn. Boca Raton: CRC Press.

Karageorgis, A. P., Katsanevakis, S., and Kaberi, H. (2009). Use of enrichment factors for the assessment of heavy metal contamination in the sediments of Koumoundourou Lake, Greece. Water. Air. Soil Pollut. 204, 243-258. doi: 10. 1007/s11270-009-0041-9

Kersten, M., and Smedes, F. (2002). Normalization procedures for sediment contaminants in spatial and temporal trend monitoring. J. Environ. Monit. 4, 109-115. doi: 10.1039/b108102k
Kring, D. A. (1997). “Composition of Earth's continental crust as inferred from the compositions of impact melt sheets," in Proceedings of the Twenty-Eighth Lunar and Planetary Science Conference, Houston, TX, 1-2.

Li, Y., Kang, C., Chen, W., Ming, L., Zhang, S., and Guo, P. (2013). Thermodynamic characteristics and mechanisms of heavy metals adsorbed onto urban soil. Chem. Res. Chin. Univ. 29, 42-47. doi: 10.1007/s40242-013-2200-1

Lin, J. G., Chen, S. Y., and Su, C. R. (2003). Assessment of sediment toxicity by metal speciation in different particle-size fractions of river sediment. Water Sci. Technol. 47, 233-241. doi: 10.2166/wst.2003. 0694

Long, E. R., Macdonald, D. D., Smith, S. L., and Calder, F. D. (1995). Incidence of adverse biological effects within ranges of chemical concentrations in marine and estuarine sediments. Environ. Manage. 19, 81-97. doi: 10.1007/ BF02472006

MacKay, H. (1994). Management of Water Quality in an Urban Estuary. Ph.D. thesis, University of Port Elizabeth, Port Elizabeth.

Mielke, H. W., Laidlaw, M. A. S., and Gonzales, C. (2010). Lead (Pb) legacy from vehicle traffic in eight California urbanized areas: continuing influence of lead dust on children's health. Sci. Total Environ. 408, 3965-3975. doi: 10.1016/j. scitotenv.2010.05.017

Navas, A., Machín, J., and Soto, J. (2005). Mobility of natural radionuclides and selected major and trace elements along a soil toposequence in the central Spanish Pyrenees. Soil Sci. 170, 743-757. doi: 10.1097/01.ss.0000185906. 18460.65

NBA (2012). South African National Biodiversity Assessment 2011: Techinical Report. CSIR Report, eds L. Van Niekerk and J. Turpie.(Stellenbosch: Council for Scientific and Industrial Research) doi:CSIR/ECOS/ER/2011/ 0045/B.

Nel, L., Strydom, N. A., and Bouwman, H. (2015). Preliminary assessment of contaminants in the sediment and organisms of the Swartkops Estuary, South Africa. Mar. Pollut. Bull. 101, 878-885. doi: 10.1016/j.marpolbul.2015. 11.015

Newman, B. K., and Watling, R. J. (2007). Definition of baseline metal concentrations for assessing metal enrichment of sediment from the south-eastern Cape coastline of South Africa. Water SA 33, 675-691.

Olguín, E. J., and Sánchez-Galván, G. (2012). Heavy metal removal in phytofiltration and phycoremediation: The need to differentiate between bioadsorption and bioaccumulation. N. Biotechnol. 30, 3-8. doi: 10.1016/j.nbt. 2012.05.020

Pedro, S., Duarte, B., Raposo, P., Almeida, D., and Caçador, I. (2015). Metal speciation in salt marsh sediments?: Influence of halophyte vegetation in salt marshes with different morphology. Estuar. Coast. Shelf Sci. 167, 248-255. doi: 10.1016/j.ecss.2015.05.034

Peppicelli, C., Cleall, P., Sapsford, D., and Harbottle, M. (2018). Changes in metal speciation and mobility during electrokinetic treatment of industrial wastes?: implications for remediation and resource recovery. Sci. Total Environ. 624, 1488-1503. doi: 10.1016/j.scitotenv.2017.12.132

Phillips, D. P., Human, L. R. D., and Adams, J. B. (2015). Wetland plants as indicators of heavy metal contamination. Mar. Pollut. Bull. 92, 227-232. doi: 10.1016/j.marpolbul.2014.12.038

Reboreda, R., and Caçador, I. (2007). Halophyte vegetation influences in salt marsh retention capacity for heavy metals. Environ. Pollut. 146, 147-154. doi: 10.1016/ j.envpol.2006.05.035

Reddering, J. S. V., Esterhuysen, K., and Rust, I. C. (1981). The Sedimentary Ecology of the Swartkops Estuary. Port Elizabeth: University of Port Elizabeth.

Roy, P. S., Williams, R. J., Jones, A. R., Yassini, I., Gibbs, P. J., Coates, B., et al. (2001). Structure and function of south-east Australian estuaries. Estuar. Coast. Shelf Sci. 53, 351-384. doi: 10.1006/ecss.2001.0796

Schropp, S. J., Graham Lewis, F., Windom, H. L., Ryan, J. D., Calder, F. D., and Burney, L. C. (1990). Interpretation of metal concentrations in estuarine sediments of Florida using aluminum as a reference element. Estuaries 13, 227-235. doi: 10.2307/1351913

Shine, J. P., Ika, R. V., and Ford, T. E. (1995). Multivariate statistical examination of spatial and temporal patterns of heavy-metal contamination. Environ. Sci. Technol. 29, 1781-1788. doi: 10.1021/es00007a014 
Smillie, C. (2015). Salicornia spp. as a biomonitor of $\mathrm{Cu}$ and $\mathrm{Zn}$ in salt marsh sediments. Ecol. Indic. 56, 70-78. doi: 10.1016/j.ecolind.2015. 03.010

Strawn, D. G., Bohn, H. L., and O'Connor, G. A. (2015). Soil Chemistry, 4th Edn. West Sussex: John Wiley and Sons.

Strawn, D., and Sparks, D. (2000). Effects of soil organic matter on the kinetics and mechanisms of $\mathrm{Pb}$ (II) sorption and desorption in soil. Soil Sci. Soc. Am. J. 64, 144-156. doi: 10.2136/sssaj2000.641144x

Tack, F. M., and Verloo, M. G. (1995). Chemical speciation and fractionation in soil and sediment heavy metal analysis: a review. Int. J. Environ. Anal. Chem. 59, 225-238. doi: 10.1080/03067319508041330

Theal, G. M. (2010). History of South Africa since September 1795, 2nd Edn. Cambridge: Cambridge University Press.

Turekian, K. K., and Wedepohl, K. H. (1961). Distribution of the elements in some major units of the Earth's crust. America (NY) 72, 175-192. doi: 10.1130/00167606(1961)72[175:doteis]2.0.co;2

Turpie, J. K., Adams, J. B., Joubert, A., Harrison, T. D., Colloty, B. M., Maree, R. C., et al. (2002). Assessment of the conservation priority status of South African estuaries for use in management and water allocation. Water SA 28, 191-206. doi: 10.4314/wsa.v28i2.4885

Ujeviæ, I., Odžak, N., and Bariæ, A. (2000). Trace metal accumulation in different grain size fractions of the sediments from a semi-enclosed bay heavily contaminated by urban and industrial wastewaters. Water Res. 34, 3055-3061. doi: 10.1016/S0043-1354(99)00376-0

Veres, D. S. (2002). A comparitive study between loss on ignition and total carbon analysis on minerogenic sediments. Stud. Univ. Babes Bolyai Geol. 67, 171-182. doi: $10.5038 / 1937-8602.47 .1 .13$

Vesper, D. J. (2012). Contamination of Cave Waters by Heavy Metals, 2nd Edn. Amsterdam: Elsevier Inc. doi: 10.1016/B978-0-12-383832-2.00024-4

Vodyanitskii, Y. N., and Shoba, S. A. (2015). Biogeochemistry of carbon, iron, and heavy metals in wetlands (Analytical review). Moscow Univ. Soil Sci. Bull. 70, 89-97. doi: 10.3103/S0147687415030072
Watling, R. J., and Emmerson, W. D. (1981). A preliminary pollution survey of the Papenkuils River, Port Elizabeth. Water SA 7, 211-215.

Watling, R. J., and Watling, H. R. (1979). Metal Surveys in Southern African Estuaries: 1. Swartkops Estuary. Port Elizabeth: Council for Scientific and Industrial Research.

Watling, R. J., and Watling, H. R. (1982). Metal surveys in South African estuaries. I. Swartkops River. Water SA 8:26.

Wentworth, C. K. (1922). A scale of grade and class terms for clastic sediments'. J. Geol. 30, 377-392. doi: 10.1086/ 622910

Williams, T. P., Bubb, J. M., and Lester, J. N. (1994). Metal accumulation within salt marsh environments: a review. Mar. Pollut. Bull. 28, 277-290. doi: 10.1016/ 0025-326x(94)90152-x

Wyatt, K. H., and Stevenson, R. J. (2010). Effects of acidification and alkalinization on a periphytic algal community in an Alaskan wetland. Wetlands 30, 1193-1202. doi: 10.1007/s13157-0100101-3

Zhang, W., Yu, L., Hutchinson, S. M., Xu, S., Chen, Z., and Gao, X. (2001). China's Yangtze Estuary: I. Geomorphic influence on heavy metal accumulation in intertidal sediments. Geomorphology 41, 195-205. doi: 10.1016/S0169$555 \mathrm{X}(01) 00116-7$

Conflict of Interest: The authors declare that the research was conducted in the absence of any commercial or financial relationships that could be construed as a potential conflict of interest.

Copyright (c) $2020 \mathrm{Nel}$, Rubidge, Adams and Human. This is an open-access article distributed under the terms of the Creative Commons Attribution License (CC BY). The use, distribution or reproduction in other forums is permitted, provided the original author(s) and the copyright owner(s) are credited and that the original publication in this journal is cited, in accordance with accepted academic practice. No use, distribution or reproduction is permitted which does not comply with these terms. 